\title{
The Pericope Adulterae and the Golden Calf: A Case for Intertextuality between Codex Bezae and the Jewish Scriptures
}

By

\section{Laurent Pinchard}

Ph.D. University of Wales, Trinity Saint David, Lampeter, United Kingdom

7 he Pericope Adulterae (henceforth PA) is a crux interpretum in New Testament textual criticism. ${ }^{1}$ It is known to be absent in many old Greek manuscripts of primary importance $\left(\mathfrak{P}^{66.75} \times \mathrm{A}^{\mathrm{vid}} \mathrm{B} \mathrm{C}^{\mathrm{vid}} \mathrm{W} \Delta^{\mathrm{c}} \Theta\right)$ as well as many later witnesses $\left(\mathrm{L}^{\mathrm{c}}\right.$ N T $\Psi$ 0141. 0211. 33. 131. 565. 1241. 1333. 1424 $4^{t x t}$. 2768) and early versions (Old Latin: a fl q; Syriac; Coptic dialects: Sahidic, Lycopolitan, proto-Bohairic and partially Bohairic manuscripts $)^{2}$. It is present, however, in a variety of other witnesses: Codex Bezae and other uncials, K L ${ }^{* \text { vid }} \Gamma \Delta^{* \text { vid }}$; minuscules, viz.118. 174. 209. 579. 700. 892, the bulk of Byzantine minuscules; some Vulgate and Old Latin texts and partial Bohairic Coptic manuscripts, all read the passage in the "traditional" place, i.e., Jn 7.53-8.11, between Nicodemus's answer to his rhetorical question involving Jewish Law on not condemning Jesus (Jn 7.50-52) and the dispute over Jesus' testimony ("I am the light of the world," Jn 8.12). However, other

\footnotetext{
${ }^{1}$ See KeIth 2008, p. 377-404, and related bibliography. See also more recently Black, CERONE 2016.

${ }^{2}$ The scribe copying Codex Vaticanus was aware of the existence of the PA in John but decided not to include it; however, he clearly marked the place by using diacritical signs - also called distigme - to mention its deliberate omission. See PAYNe, CANART 2000, p. 112.
} 
manuscript evidence exists to show that there was disagreement over the location of the PA. Two late minuscules of $f^{1}, 1$ and 1582, include the PA at the end of John; a family of other minuscules, $f^{13}$, include it at the end of Luke 21 before the plot against Jesus. Additionally, a minority of manuscripts attest other locations. ${ }^{3}$ The ambiguity of the exact location of the PA is further evidenced by a series of dotted crosses, or obeli, found in two witnesses, namely the early $11^{\text {th }}$ c. minuscule 230 and in the margin of $1424\left(1424^{\mathrm{mg}}\right)$. In total, there are no less than eight different locations for the PA in the textual tradition. ${ }^{4}$

In terms of internal evidence, existing scholarship has convincingly demonstrated the nonJohannine character of the vocabulary of the PA, showing that it is better suited to one of the Synoptics, though it is included in John in our NT editions. ${ }^{5}$ The absence of a clear conclusion as to its original location has therefore led the editors of the Nestle-Aland to mention it in double square brackets, as indicating a passage "known not to be a part of the original text" but "deriv[ing] from a very early stage of the tradition."

\section{Intertextual Links between the Pericope Adulterae and the Torah}

The most recent substantive study was carried out by Chris Keith, who examined the passage from the perspective of Historical Jesus Studies, as a contribution to discussions concerning the literacy of Jesus (KEITH 2009a). Keith highlights the intertextual link of the

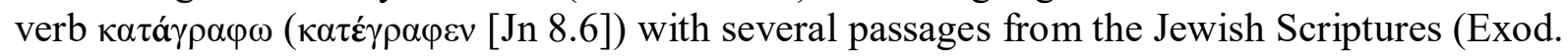
17.14; 32.15; Num. 11.26; 1 Chr. 9.1; 2 Chr. 20.34; 1 Esd. 2.12; Job 13.26; Sir. 48.10; Hos. 8.12; 1 Macc. 9.22; 14.26). ${ }^{7}$ He isolates the passage of the Golden Calf and notes that only a few of the Church Fathers, namely Ambrose, Jerome, and Augustine ${ }^{8}$ cross-reference the episode of the PA with the Book of Exodus (chap. 31-32), the basis being the existence of

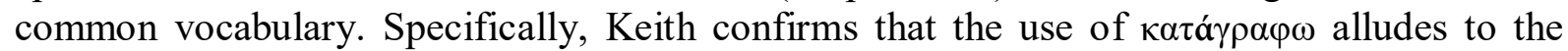

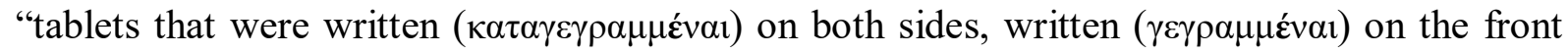
and on the back," (Exod. 32.15) and that they were written "with [his] finger" ( $\tau \tilde{\omega}$ $\delta \alpha \kappa \tau v \lambda \omega$; Exod. 31.18).

The existence of intertextual links between Scriptural books or passages has been given particular attention among biblical scholars in recent decades, as the concept of "intertextuality" as a literary and exegetical approach has been given increasing recognition, though in terms of methodology there remains no little disagreement. Keith, for example, uses the work of D.C. Allison who lists six criteria that allow a passage to be considered intertextually relevant (ALLISON 2000, p. 10-13): ${ }^{9}$ (1) plausibility of the allusion; (2) common

\footnotetext{
${ }^{3}$ A supplementary folio in minuscule 1333 (originally without the PA) adds the PA immediately after Lk.

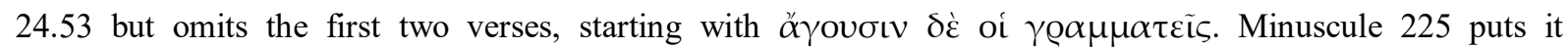
immediately after Jn 7.36 .

${ }^{4}$ Seven are identified by ROBINSON 2000, p. 35-59.

${ }^{5}$ See a summary and related bibliographical references to the question in KEITH 2008, p. 379-381. On counter-arguments, see PUNCH 2016, p. 7-32.

${ }^{6}$ Nestle-Aland, $28^{\text {th }}$ ed., $55^{*}$.

${ }^{7}$ KEITH 2009a, p. 38-47, identified also a variant reading in Ezekiel 8.10 as a variant reading in Symmachus' translation.

${ }^{8}$ References are given in KEITH 2009a, p. 6, 12. A more detailed presentation of the comments of Ambrose, Jerome, and Augustine on the PA in relation to the Golden Calf can be found in KNUST 2006, p. 485-536.

${ }^{9}$ The criteria are described by KEITH 2009a, p. 181-187.
} 
lexical or thematic links; (3) similarity due to unconventional vocabulary; (4) prominence of the other story referred to; (5) interest of the author in the intertext; (6) importance of the hypotext in the context of the hypertext. Provided that allusions pass the test of these criteria, the parallel passages should not be viewed as "far-fetched" correspondences but rather are to be understood as clear and deliberate references. Keith cites one of the most striking exegetical conclusions as being that "Jesus" writing in these passages should be understood in terms of "God's authorship of the Decalogue" and that "[Jesus] wrote on the ground with the finger with which He had written the Law" (KEITH 2009a, p. 179-181). ${ }^{10}$

Keith is not, in fact, the first modern scholar to see the parallels between the PA and the book of Exodus. These had already been explored by Rius-Camps in his first 1993 article on the subject (RIUS-CAMPS 1993, p. 171-173), ${ }^{11}$ where he paid particular attention to textual variants, highlighting the fact that the text of one early manuscript, Codex Bezae Cantabrigensis, a bilingual Greek/Latin uncial copied around $400 \mathrm{CE}^{12}$ but with a text rooted in the $2^{\text {nd }}$ c., ${ }^{13}$ contains several key references to the incident of the Golden Calf that are absent from other manuscripts. ${ }^{14}$ The result is that the grounding of the PA in the Golden Calf incident is particularly strong in the Bezan text, a result that I had found independently, ${ }^{15}$ and the reason for which I would like to explore further the intentionality and purpose of the connection that these scholars draw attention to, and to consider how this may affect its placing within the Gospels.

Scholarly discussion on the quest for the origin of the PA has also been engaged several times by the French textual critic C.-B. Amphoux (2014, p. 348-369, and 1996, p. 337-354). On the occasion of a recent Festschrift, he suggested that the question of the placing of the PA is related to seeing how the writing of Jesus twice in the ground represents that "re-writing" of the Law on Mount Sinai (AMPHOUX 2013a, p. 161).

Whatever the precise implications of the parallels between the PA and the book of Exodus for the meaning of the Gospel passage, the nature of the intertextual connection is worthy of further consideration within the specific context of $1^{\text {st }}$ century Judaism, which I will seek to

\footnotetext{
${ }^{10}$ See the explicit reference to the "finger" in AMBrose, Epistle 68 (26), Spir. 3.3.14-16.

${ }^{11}$ Rius-Camps further developed his own views in a later article (2007, p. 379-405). The latter article is noteworthy for the identification to which his analysis leads of distinct strands of Markan and Lukan versions of the PA.

12 The Latin page of the Greek text of the PA will not be considered in this article. The analysis will remain on the earlier, Greek page. The relationships between D and d are complex and thoroughly described in Parker's monograph on Codex Bezae (PARKER 1992).

${ }^{13}$ An earlier date than the $2^{\text {nd }}$ c. for the Bezan text is implicitly suggested by RIUS-CAMPS, READHEIMERDINGER 2014, p. xiii.

${ }^{14}$ Keith does mention Rius-Camps' articles, but only in passing, starting his research afresh from the occurrences of $\kappa \alpha \tau \alpha \dot{\gamma} \gamma \rho \alpha \varphi \omega$ then embarking on the discussion on $\tau \tilde{\omega} \tilde{\omega} \delta \alpha \kappa \tau \nu \lambda \omega$.

${ }^{15}$ It was while preparing this passage as part of a group of Christians of Jesuit inspiration (CLC, Christian Life Community) that I found striking similarities between the two texts by concentrating on the Bezan text of the PA, before being acquainted with the work of either Keith or Rius-Camps. I had originally noted that the repetitions in Codex Bezae of $\kappa \alpha \tau \varepsilon ́ \gamma \varrho \alpha \varphi \varepsilon v$ but also the twice repeated phrase $\tau \tilde{\omega} \delta \alpha \kappa \tau \dot{\lambda} \lambda \omega$, as well as Jesus going up and down twice (8.7/8.8 $\alpha \dot{v} \varepsilon ́ \kappa v \psi \varepsilon v / \kappa \alpha \tau \alpha \kappa u ́ \psi \alpha \varsigma)$ were unlikely to be the consequence of some erratic scribal whim for they are characteristic of Jewish exegetical techniques. Summarising the evidence, on the basis of a lexical analysis of both passages in Codex Bezae, I found that the entire PA relates to Moses receiving the Ten Commandments for his people in general and the Golden Calf as a paradigmatic representation of the sin of Israel in particular (see section 5 below).
} 
address here. My objectives in this article are, thus, to collate and review some of the salient conclusions reached by the research on the PA by Keith, Rius-Camps and Amphoux, and consider them in the light of my own conclusions, with the overall aim of advancing the discussion on the authenticity and placing of the PA.

\section{Codex Bezae as a Key Representative of a Variant Text of the PA}

Codex Bezae is a manuscript of the first order in the understanding of the development of the textual traditions of the Gospels (and Acts) because its text so often departs from other key witnesses, notably the generally preferred Alexandrian manuscripts Codex Vaticanus and Codex Sinaiticus, but it has the support of a wide range of early versions that date from the first centuries, before the standardisation of the New Testament text. Unsurprisingly, this is also the case with the PA where the mainly Alexandrian witnesses omit the passage while Codex Bezae includes it.

The collation of all the variant readings in the PA that are attested by the entire manuscript tradition is a gigantic effort, which is made partially possible at least by consulting the critical apparatus offered in the $28^{\text {th }}$ edition of the Nestle-Aland. Despite its unfortunate simplification due to its pocket size, I will refer in this article to the variant readings mentioned in the $28^{\text {th }}$ edition of Nestle-Aland's Greek New Testament $\left(\mathrm{NA}^{28}\right)$, since these are readily available to readers. ${ }^{16}$ Even though simplified, the presentation of its critical apparatus as a string of variant readings remains extremely complex and further classification is needed. It is noteworthy that a large proportion of the variant readings are distinctively singular or sub-singular in Codex Bezae: out of the 35 Bezan variant readings, $19(\sim 55 \%)$ are singular or sub-singular, ${ }^{17}$ thereby denoting a quite distinct text.

Such singular or sub-singular readings can be grouped into individual clusters of variation. As is common practice in text-critical studies, a grouping into omissions, additions, substitutions, changes in word order and transposition may be useful. However, because there is technically no text of reference for the PA, except the eclectic reconstruction of $\mathrm{NA}^{28}$, one should prefer reference to the larger and objective concepts of "presence," "absence," "alternative wording," "word order difference" and "alternative location." The resultant clusters of variation are as follows:

\section{Alternative wording in Codex Bezae}

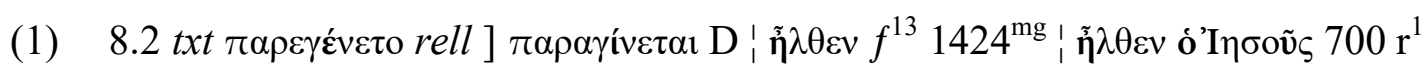

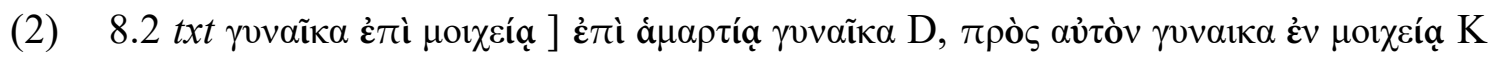
$579 \mathrm{pm} \mathrm{c} \mathrm{ff}^{2}\left(\mathrm{vg}^{\mathrm{mss}}\right)$

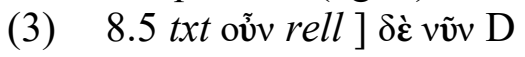

\footnotetext{
${ }^{16}$ I have reviewed the variant readings in the Bezan text by checking Scrivener's edition 1978, and noticed,

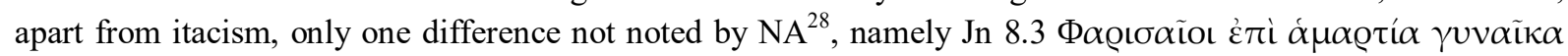

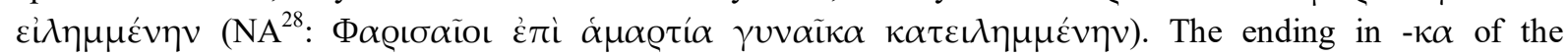

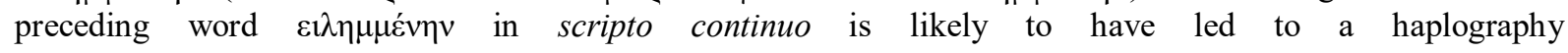

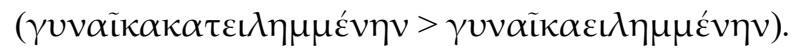

17 "Singular readings" are readings that are not found elsewhere in the extant manuscript tradition. What I mean by "sub-singular" readings are readings that are found only "in isolated agreements with one or a few other witnesses," as explained in FEE 2012, p. 204. On the array of definitions of sub-singular readings, see EPP 2005, p. 110-111, and 2007, p. 278, n. 8 .
} 


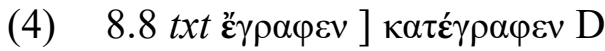

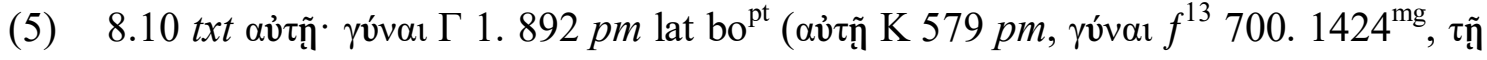
үuvaikí D c)

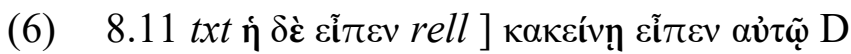

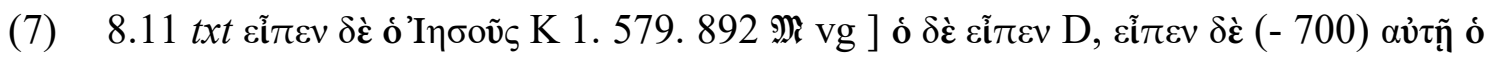

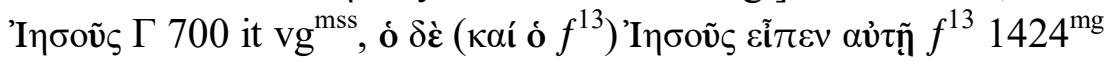

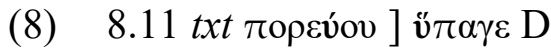

\section{Absence of words in Codex Bezae}

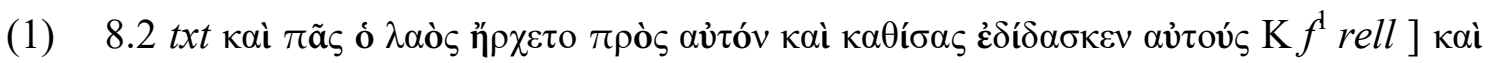

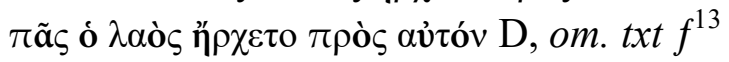

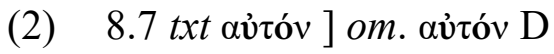

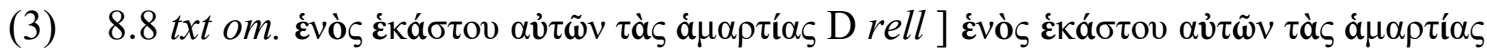
700

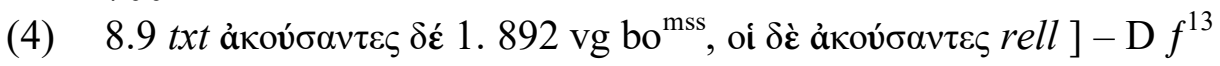

\section{Presence of words in Codex Bezae}

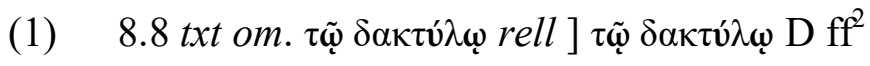

\section{Word order differences}

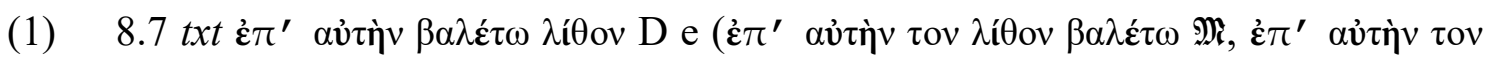

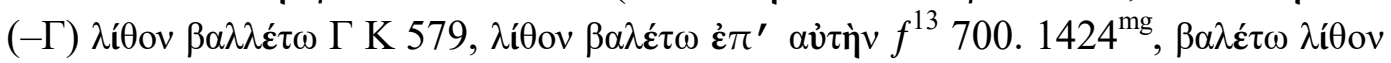

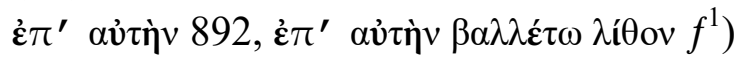

\section{Combinations of the above classifications}

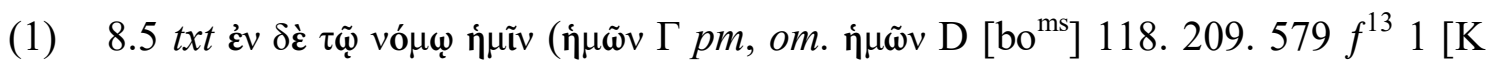

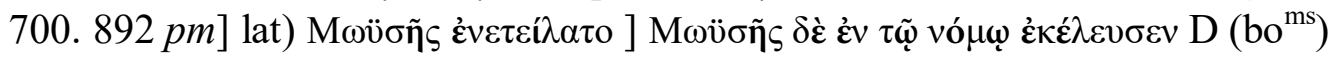

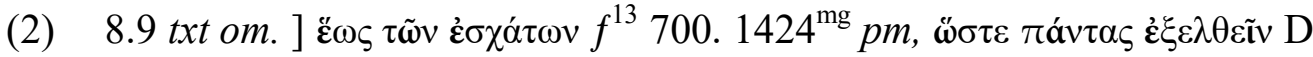

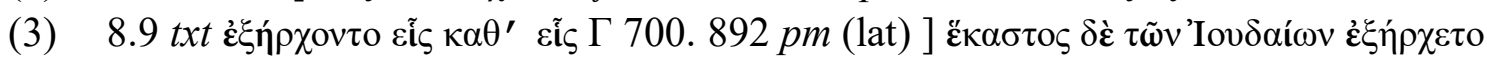
D

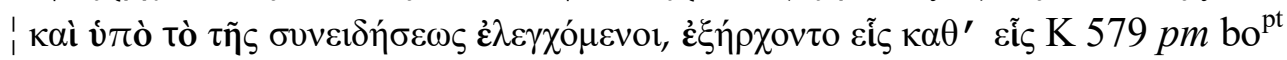

\section{Transposition}

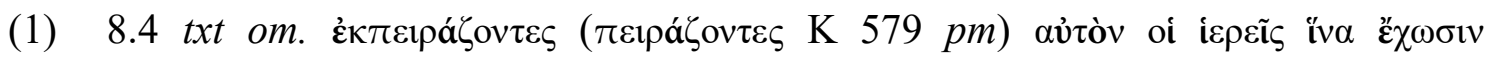

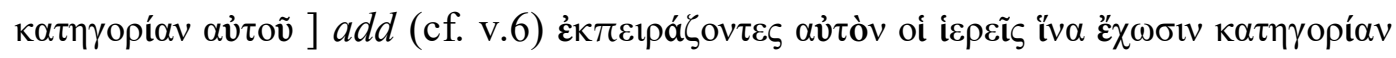
$\alpha$ ข่นกี̃ D

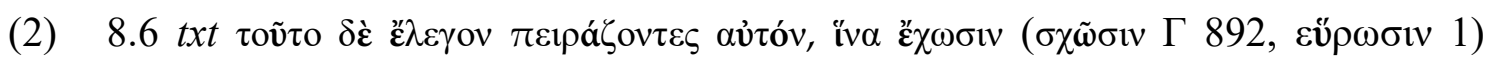

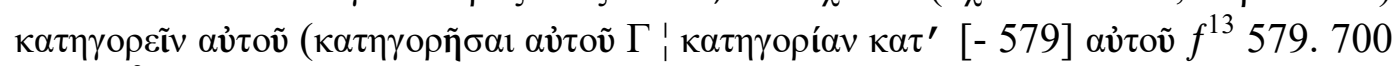
pm $\mathrm{c} \mathrm{ff}^{2}$ bo) ] om. (cf. 4.11 v.l.) D 
The remaining 16 readings are shared by Codex Bezae and other manuscripts but are variant in others; these have all been incorporated into the edited text (and labelled " $t x t$ " in the critical apparatus). The Bezan readings where $t x t$ is chosen are as follows:

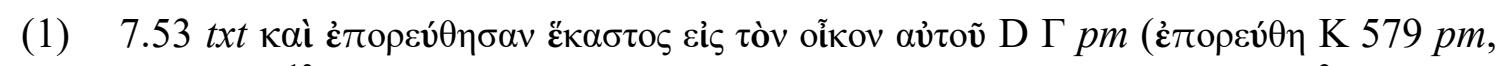
$\dot{\alpha} \pi \tilde{\eta} \lambda \theta \varepsilon v f^{13} \mathrm{pm}, \dot{\alpha} \pi \tilde{\eta} \lambda \theta$ ov $700.1424^{\mathrm{mg}}$, tó $\pi$ ov 1. 892) ] om. v.53 in full $\mathrm{ff}^{2}$

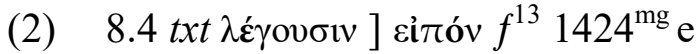

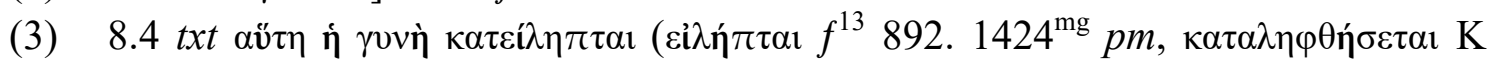

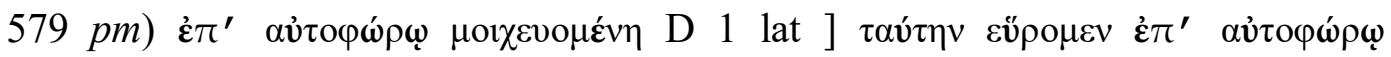

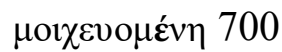

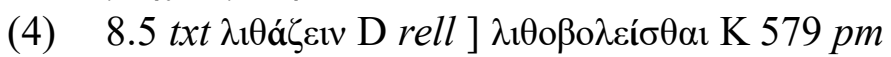

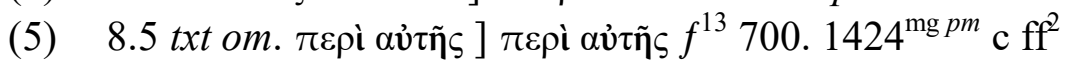

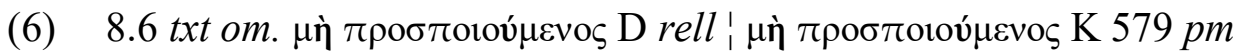

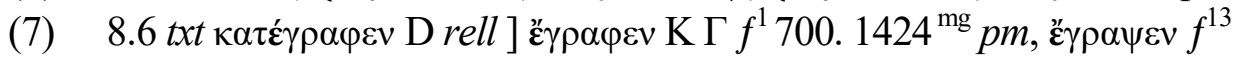

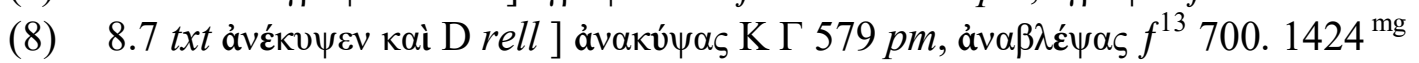

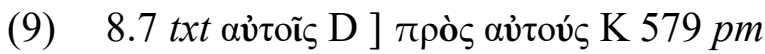

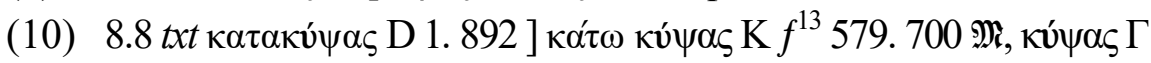

(11) 8.9 txt oũ $\sigma \alpha \mathrm{D}$ rell ] $\dot{\varepsilon} \sigma \tau \tilde{\omega} \sigma \alpha 1.892$ lat, $-\mathrm{e}$

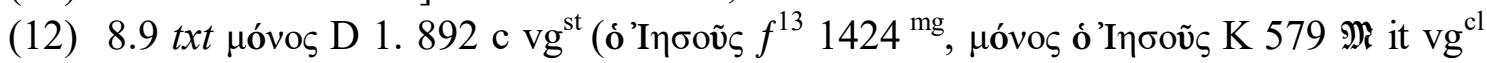
bo $^{\mathrm{pt}}$, ó (-700)'I

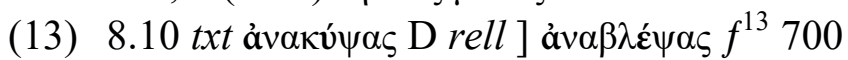

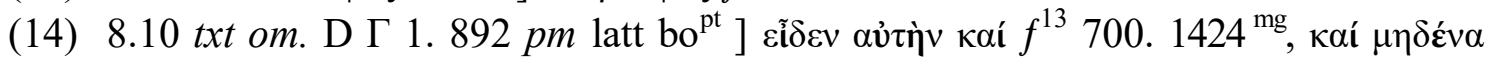

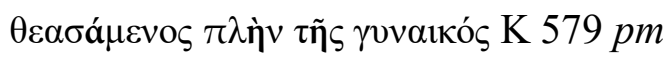

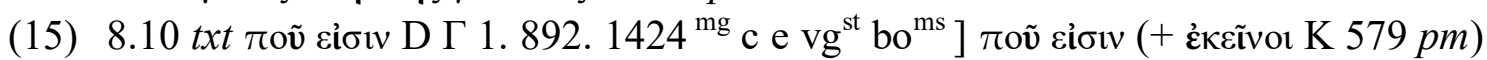

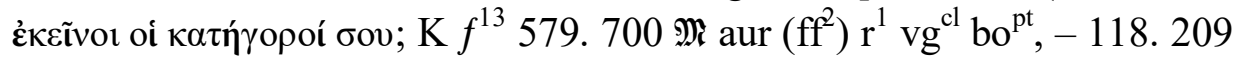

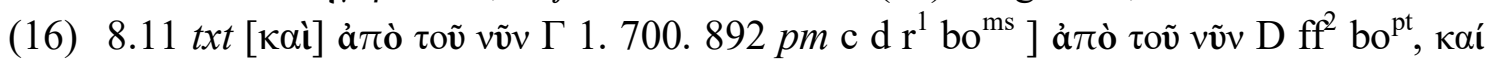
$\mathrm{K} 579.1424^{\mathrm{mg}} \mathrm{pm}$ lat, $-f^{13}$

As a consequence, a little more than half of the other variant readings were rejected by the editors in the belief that they depart from the earliest, so-called Ausgangstext and these are therefore identified in the critical apparatus as secondary. Interestingly, all of them are readings where Codex Bezae attests either singular or sub-singular variants, except where the reading is equally variant among other witnesses.

\section{List of the Significantly Distinctive Bezan Readings in the PA}

There are important differences among those listed in the aforementioned distinctive readings that are worthy of special mention, and I will now deal with those in more detail. While some of them are analysed by Rius-Camps in a summarised (RIUS-CAMPS 1993, p. 171-173) or more extensive (2007, p. 387-395) form according to their alleged synoptic origin, I will list my findings and analysis below as the text runs:

1. Codex Bezae is the only manuscript not to introduce the passage by mentioning a

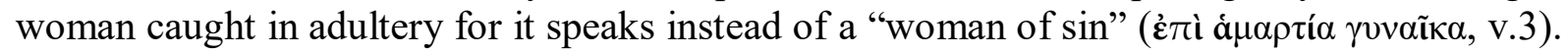
A similar expression is found in Eusebius of Caesarea who identified the passage as 
belonging to a now lost writing of the $2^{\text {nd }}$ c. Church Father Papias. ${ }^{18}$ According to Eusebius, Papias mentions a story "about a woman who was accused of many sins before the Lord"

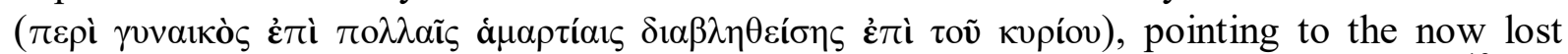

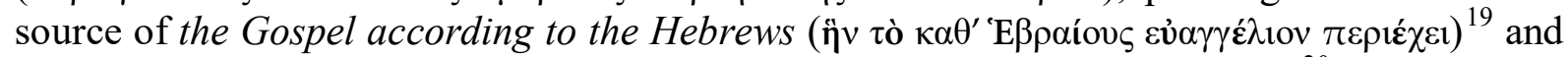
using wording that strikingly resembles the singular reading in the Bezan text. ${ }^{20}$ This suggests that the reading was known in the $2^{\text {nd }} \mathrm{c}$., thereby demonstrating its antiquity. Yet, the origin of the quotation not only confirms that the text was not originally found in the Gospel of John but also indicates that the expression "caught in adultery" is a later development despite its being the reading of all the manuscripts which contain the PA except Codex Bezae.

How is this important for the story of the PA? When hearing the reference to "sin," a firstcentury Jewish audience may have immediately called to mind a "sin" of especial importance - the one of Israel's idolatry as exemplified in the Golden Calf episode, as will be clarified later in this article. The reference to "sin" would then gradually have become blurred for an audience of non-Jewish origin and would eventually have been substituted in the manuscript tradition to introduce the then well-known story of the woman "caught in adultery." Such a move within the tradition is traceable in the lexical duplication with words of the following

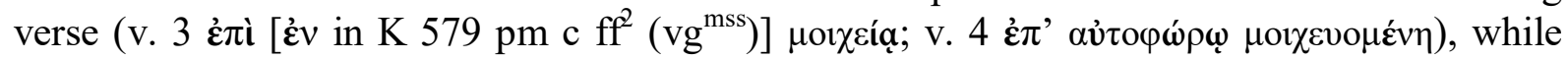
Codex Bezae retains what would have been an earlier form.

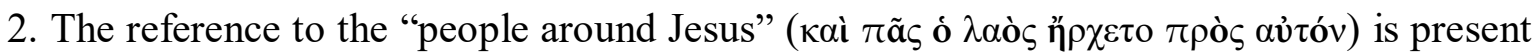
in almost the whole of the tradition, except in $f^{13}$ where it is not read at all. The phrase "all the people" ( $\pi \tilde{\boldsymbol{\alpha}} \varsigma \dot{\boldsymbol{o}} \lambda \alpha \boldsymbol{o} \varsigma)$ is a familiar reference to designate the people of Israel (RIUS-CAMPS 1993, p. 171), ${ }^{21}$ which is also used specifically in the context of the Golden Calf. Further, in all traditions, except Codex Bezae and $f^{3}$, a reference to the "sitting and teaching them" (кaì $\kappa \alpha \theta i ́ \sigma \alpha \varsigma \dot{\varepsilon} \delta \dot{\delta} \delta \alpha \sigma \kappa \varepsilon v \alpha \dot{v} \tau o v ́ \varsigma)$ is attested. The latter clause is characteristic of synoptic vocabulary which is typically used when Jesus is teaching in an authoritative position. ${ }^{22}$ It probably appears here as a result of natural expansion, as a means to confer further authority on Jesus in relation to the Jews. In consequence, Codex Bezae only has a reference to "the people com[ing] to him," a phrasing that could serve as a reminder of "all the people" gathering around one person (here: Aaron) in the Golden Calf episode (Exod. 32.1).

3. There is an apparently insignificant change in the word order of one the constituents of the clause in v.5, whereby it is the subject "Moses" that appears in the first position in the Bezan verse as opposed to the prepositional phrase in other manuscripts. Such a position is defined by linguistic studies in the field of discourse analysis as giving a highly prominent character to the fronted element. ${ }^{23}$ It may be supposed that the reason for this order in Codex

\footnotetext{
${ }^{18}$ Hist. Eccl., III.39, 16.

${ }^{19}$ Hist. Eccl., III.39, 17.

${ }^{20}$ On the potential issue involved in Papias' reference to "many sins" (plural) as opposed to "sin" (singular), see KNUST 2006, p. 495.

${ }^{21}$ The occurrences of $\pi \tilde{\alpha} \varsigma$ ó $\lambda \alpha$ ós are extremely wide spread in the Jewish Scriptures, namely in Exodus (Exod. 11.8; 18.13,18,23; 19.8,16,18; 20.18; 24.3; 32.3; 33.8,10; 34.10) and Deuteronomy (Deut. 2.32; 3.1; $17.13 ; 20.11 ; 27.15-17$;) compared to Leviticus (only 9.24) and Numbers (only 13.32; 21).

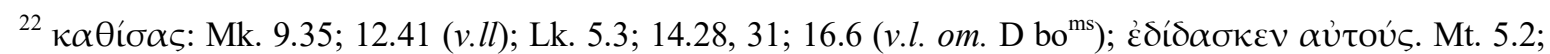
13.54; Mk. 2.13; 4.2; 10.1 .

${ }^{23}$ For the linguistic analysis demonstrating the prominence of constituents in preverbal position, see LEVINSOHN 2000. For its consequences to and application to textual criticism, see READ-HEIMERDINGER 2002, p. $62-115$.
} 
Bezae was to link Jesus and Moses closely together as persons, as opposed to the order found in the other manuscripts which reflects rather an attempt to highlight the legalistic significance of the woman's $\sin .^{24}$

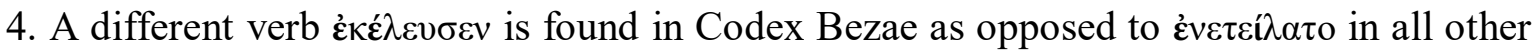
manuscripts. Though the equivalents in English translation scarcely differ, the form $\dot{\varepsilon} \kappa \varepsilon \dot{\varepsilon} \varepsilon v \sigma \sigma \varepsilon v$ ( $\kappa \varepsilon \lambda \varepsilon v \omega \omega$, order, ordain) is strikingly the form found exclusively in deutero-canonical Jewish Scriptures. ${ }^{25}$ It is also typical of Lukan vocabulary, with some rarer occurrences in Matthew. ${ }^{26}$ The form $\dot{\varepsilon} v \varepsilon \tau \varepsilon \dot{\imath} \lambda \alpha \tau$ ( $\dot{\varepsilon} v \varepsilon \dot{\varepsilon} \lambda \lambda \omega$, command) is, in contrast, predominantly that used in the LXX, with some traces in the New Testament. ${ }^{27}$ It is somewhat intriguing why Bezae reads $\dot{\varepsilon} \kappa \varepsilon \dot{\lambda} \varepsilon v \sigma \varepsilon v$ while the rest of the textual tradition has $\dot{\varepsilon} v \tau \varepsilon \dot{\lambda} \lambda \lambda \omega$. It may be suggested that the

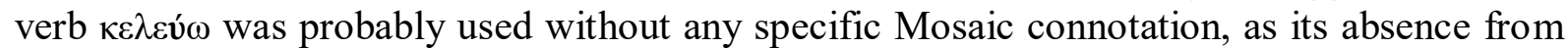
the canonical Jewish Scriptures testifies, whereas, $\dot{\varepsilon} v \tau \dot{\varepsilon} \lambda \lambda \omega$, a verb that is mostly attributed to God, may have been substituted here in a context where Moses takes precedence in the legalistic discussion (Lev 20.10).

5. There is divergence concerning the pronoun, whether dative "to/for us" (íñv) in $f^{13} 1$ (K 700. $892 e$ ) lat, the genitive "our" ( $\dot{\eta} \mu \tilde{\omega} v)$ in $\Gamma ~ p m$, or absence in Codex Bezae. ${ }^{28}$ In any case, the emphasis on Moses in the comment of the Jewish leaders can be seen as linked to his role as the intermediary between God and the people, a status which refers back to the Golden Calf episode, maintaining the focus on the paradigmatic incident in the Torah rather than on the incident of the woman brought before Jesus.

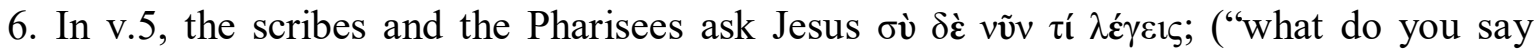
now?"). Only Codex Bezae attests the adverb vĩv ("now") while the rest of the traditions uses oũv ("so"). Nũv is the Greek translation of the Hebrew עתה which appears several times in Exod. 32-33 (32.10, 30, 32; 33.5), especially when God and Moses discuss immediate judgement that can involve death after sin. This forceful challenge by the Jewish leaders commanding Jesus to give an answer "now" may well be linked on this basis to the Golden Calf episode. The adverb oũv in the other manuscripts is a typical developmental marker in Johannine narrative, which may have slipped in when the passage was integrated into John (AMPHOUX 2013a, p. 153).

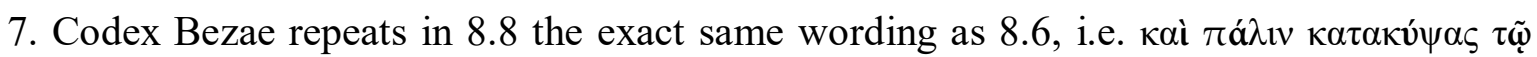

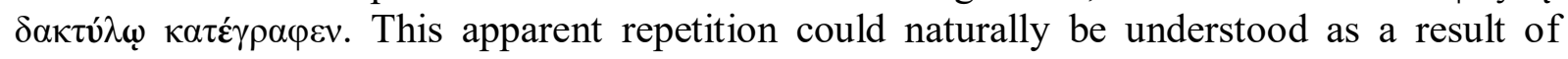
harmonisation with the immediate context, but I suggest that this is a deliberate attempt to attract the attention of the reader to the two writings with "[God's] finger" on the Tablets of the Covenant in Exod. 31 and 33. Equally, on the basis of this reasoning the repetition of

\footnotetext{
${ }^{24}$ As it is often the case in discourse analysis, the meaning remains unchanged but the prominence is affected, in accordance with the intention of the writer/editor.

${ }^{25} \kappa \varepsilon \lambda \varepsilon u ́ \omega: ~ J d t . ~ 2.15 ; 12.1 ;$ Tob. 8.18; 1 Macc. 11.23; 2 Macc. 1.20-21,31; 2.1,4; 5.12; 7.5; 13.12; 14.31; 3 Macc. 5.2,16; 6.30; 4 Macc. 8.2,12; 10.17; Sut. 1.56). Cf. Lk. 18.40; Acts 5.34; 8.38; 12.19; 21.33-34; 22.24,30; $23.10 ; 25.6 ; 27.43$; Mt. 8.18; $14.9 ; 18.25 ; 27.58$.

${ }^{26}$ Surprisingly, Rius-Camps does not analyse the Matthean, distinctively Bezan form, which would have been expected to be Markan, according to his thesis (RIUS-CAMPS 2007, p. 389).

${ }^{27}$ Mt. 17.9; 19.7; Mk. 10.3; 13.34; Jn 8.5; 14.31; Heb 9.20; 11.22. For a discussion on the characteristically Lukan vocabulary in the PA, see HuGHES 2013, p. 232-251.

${ }^{28}$ It can be suggested that the reason for not using the pronoun in Codex Bezae is because its text corresponds to a time of composition when all participants were part of the same Jewish community and where such a precision was unnecessary.
} 
$\kappa \alpha \tau \varepsilon$ र $\rho \alpha \varphi \varepsilon v$ in Codex Bezae belongs most probably to the original composition; it would have been simplified in other traditions because of syntactical redundancy. ${ }^{29}$

8. Codex Bezae alone insists, against the rest of the tradition, on the disappearance of all

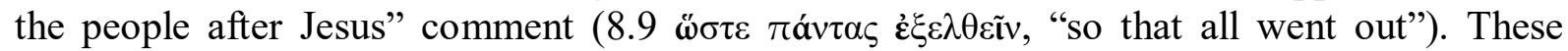
words repeat what has already just been said, that all the people had "[gone] away, one by one, beginning with the elders," and that "Jesus was left alone with the woman standing before him." It may be asked why a scribe would have deliberately added superfluous words ("so that all went out") to a sentence which was already quite clear. On the contrary, it can be seen as much more likely that a process of scribal simplification prompted the elimination of this clause. The reason for the apparently unnecessary presence of these words in Codex Bezae can be seen as a deliberate device to alert the reader to a similar development in Exod. 33 where the people are outside the camp and leave Moses alone in the Tent of Meeting. ${ }^{30}$

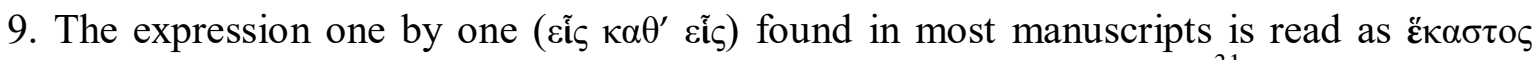
("each one") in Codex Bezae, interestingly just as in Exod. 32.27, 29; 33.8. ${ }^{31}$

10. Despite the $\mathrm{NA}^{28}$ text following Codex Bezae with a few other manuscripts (mainly

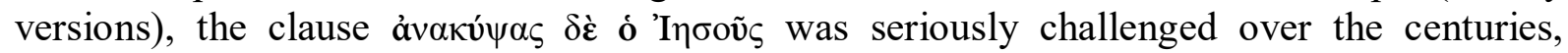
generating various verbal expansions and a lexical substitution involving the participle $\grave{\alpha} v \alpha \beta \lambda \varepsilon ́ \psi \alpha \varsigma$. While both verbs "make sense" from an narrative point of view, à $v \alpha \kappa v ́ \psi \alpha \varsigma$ serves as an echo of the symmetrical structure of the Exodus text on which the passage is based, pointing implicitly to Moses going up and down Mount Sinai to receive the Tablets of the Covenant before and after the episode of the Golden Calf (Exod. 31 and 33), as will be suggested in the next section.

\section{Comparison of the Lexical and Thematic Similarities between the PA in Codex Bezae and the Episode of the Golden Calf}

In presenting the singular or sub-singular readings in Codex Bezae above, a number of verbal parallels with the story of the Golden Calf were identified. I will now set out the PA and an outline of Exod. 31-33 in synoptic arrangement, as a means to identify thematic and lexical similarities between the two passages (words in boldface refer to singular or subsingular Bezan readings):

\begin{tabular}{|c|c|c|c|c|}
\hline & \multicolumn{2}{|c|}{ Codex Bezae (Jn 7.53-8.11) } & \multicolumn{2}{|c|}{ Exod. 31-33LXX } \\
\hline 1 & 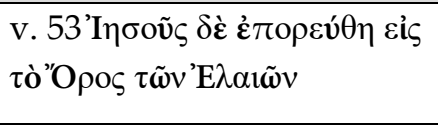 & $\begin{array}{l}\text { Jesus goes to } \\
\text { the Mont of } \\
\text { Olives }\end{array}$ & 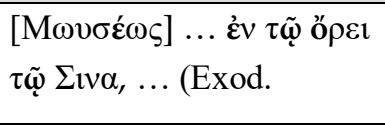 & $\begin{array}{l}\text { Moses is on the } \\
\text { mountain (Exod. } \\
24-32 \text { ) }\end{array}$ \\
\hline
\end{tabular}

${ }^{29}$ The tradition is split with all possible combinations of है $\gamma \varrho \alpha \varphi \varepsilon v / \kappa \alpha \tau \varepsilon \dot{\varepsilon} \gamma \varrho \alpha \varphi \varepsilon v$ in 8.6/8.8 (8.6 है $\gamma \varrho \alpha \varphi \varepsilon v \mathrm{~K}$

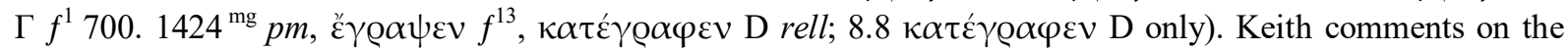
use of two different verbs because he uses the Alexandrian text of Nestle-Aland, where the two are used (KEITH 2009a, p. 183). The reference to Exodus 32 is therefore all the more prominent in Codex Bezae because of the

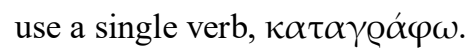

${ }^{30}$ The common word $\varepsilon_{\xi} \xi \dot{\varepsilon} \mathrm{Q} \chi \mu \alpha \mathrm{\iota}$ is a key verb in the Book of Exodus. It is the translation of the two Hebrew verbs עלה ("to go up") and ("to go out") that are characteristic of the people's exodus outside of Egypt, after God called his people by the voice of Moses. This Bezan reading could potentially be a further allusion to Exodus.

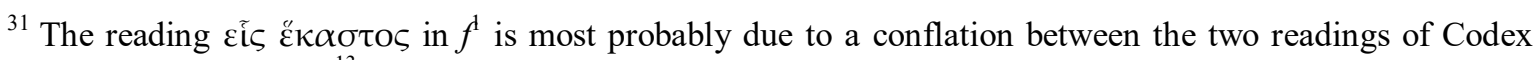
Bezae and, among others, $f^{3}$.
} 


\begin{tabular}{|c|c|c|c|c|}
\hline & \multicolumn{2}{|c|}{ Codex Bezae (Jn 7.53-8.11) } & \multicolumn{2}{|c|}{ Exod. 31-33LXX } \\
\hline & & & $31.18 \mathrm{a})$ & \\
\hline 2 & v. 2’O $\rho \theta \rho \circ v$ & $\begin{array}{l}\text { In the } \\
\text { morning }\end{array}$ & 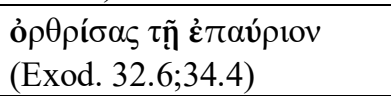 & $\begin{array}{l}\text { In the morning of } \\
\text { the following day }\end{array}$ \\
\hline 3 & 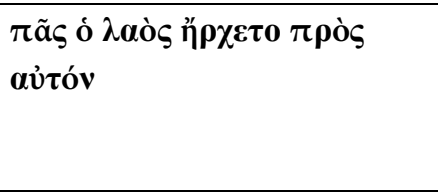 & $\begin{array}{l}\text { All the people } \\
\text { came to him }\end{array}$ & 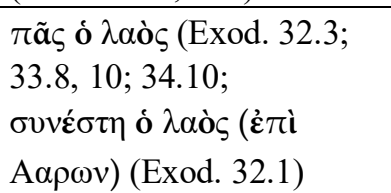 & $\begin{array}{l}\text { all the people - the } \\
\text { people gathered } \\
\text { (around Aaron) }\end{array}$ \\
\hline 4 & 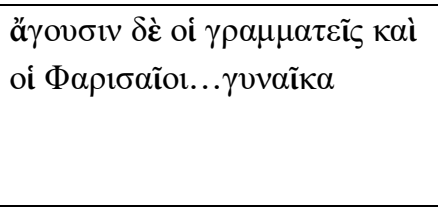 & $\begin{array}{l}\text { The scribes } \\
\text { and the } \\
\text { Pharisees } \\
\text { brought a } \\
\text { woman }\end{array}$ & 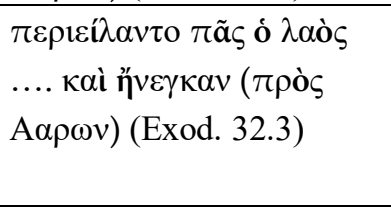 & $\begin{array}{l}\text { all the people took } \\
\text { off [the gold rings } \\
\text { from their ears] } \\
\text { and brought them } \\
\text { (to Aaron). }\end{array}$ \\
\hline 5 & 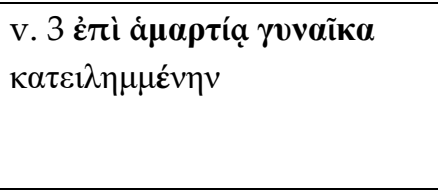 & $\begin{array}{l}\text { The woman } \\
\text { was caught in } \\
\text { sin }\end{array}$ & 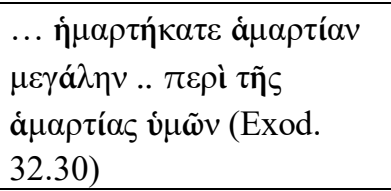 & $\begin{array}{l}\text { "You have sinned } \\
\text { a great sin. ... } \\
\text { atonement for your } \\
\text { sin." }\end{array}$ \\
\hline 6 & 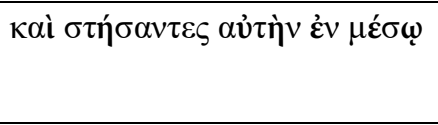 & $\begin{array}{l}\text { They place } \\
\text { her in the } \\
\text { middle }\end{array}$ & 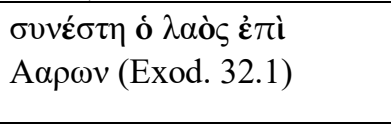 & $\begin{array}{l}\text { the people } \\
\text { gathered around } \\
\text { Aaron }\end{array}$ \\
\hline 7 & 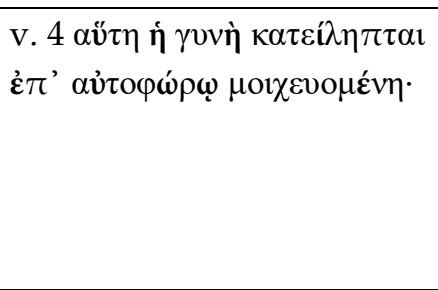 & $\begin{array}{l}\text { The woman } \\
\text { was caught in } \\
\text { the very act } \\
\text { of committing } \\
\text { adultery. }\end{array}$ & 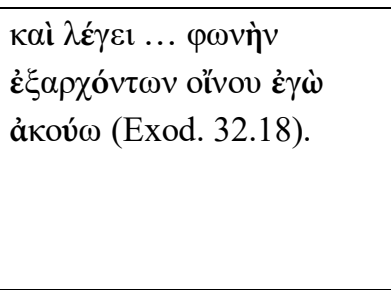 & $\begin{array}{l}\text { [the Golden Calf } \\
\text { episode: Moses } \\
\text { catches the people } \\
\text { in an idolatrous, } \\
\text { metaphorically } \\
\text { adulterous, } \\
\text { situation] }\end{array}$ \\
\hline 8 & 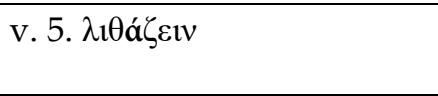 & to stone & 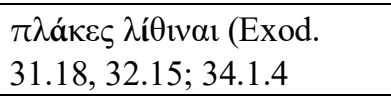 & tablets of stone \\
\hline 9 & 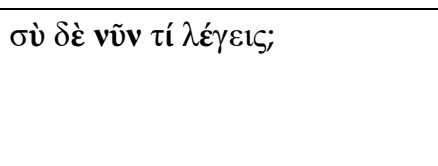 & $\begin{array}{l}\text { and what do } \\
\text { you say now? }\end{array}$ & $\begin{array}{l}\text { vṽv (Exod. 32.10, 30, 32; } \\
\text { 33.5) }\end{array}$ & $\begin{array}{l}\text { [discussion } \\
\text { between Moses and } \\
\text { God and immediate } \\
\text { judgment] }\end{array}$ \\
\hline 10 & 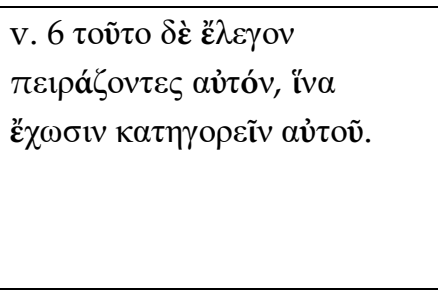 & $\begin{array}{l}\text { They said this } \\
\text { to test him, so } \\
\text { that they } \\
\text { might have } \\
\text { some charge } \\
\text { to bring } \\
\text { against him. }\end{array}$ & 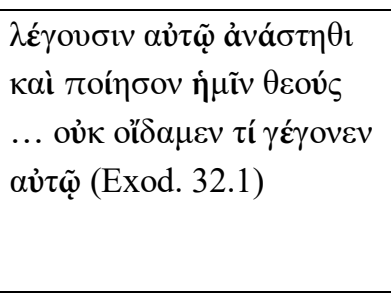 & $\begin{array}{l}\text { [the people put } \\
\text { Aaron to the test] }\end{array}$ \\
\hline 11 & 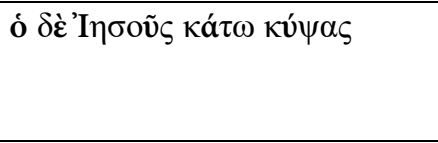 & $\begin{array}{l}\text { Jesus bent } \\
\text { down }\end{array}$ & 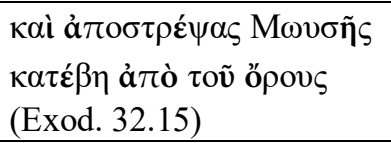 & $\begin{array}{l}\text { Moses went down } \\
\text { from the mountain }\end{array}$ \\
\hline 12 & $\tau \tilde{\omega} \tilde{\omega} \delta \alpha \kappa \tau v \dot{\lambda} \omega$ & $\begin{array}{l}\text { with his } \\
\text { finger }\end{array}$ & $\tau \tilde{\omega} \tilde{e} \delta \alpha \kappa \tau u ́ \lambda \omega \underline{\omega}($ Exod. 31.18) & with his finger \\
\hline 13 & 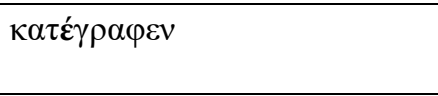 & he wrote & 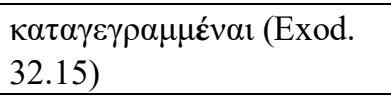 & written/inscribed \\
\hline 14 & $\varepsilon \dot{c} \zeta \tau \grave{\eta} v \gamma \tilde{\eta} v$ & in the ground & 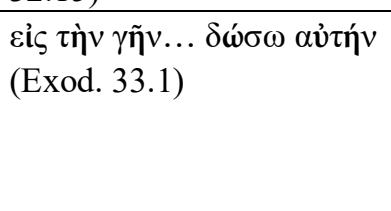 & $\begin{array}{l}\text { Moses is told to go } \\
\text { with the people } \\
\text { in[to] the land (Gk. } \\
\text { "the ground") God } \\
\text { will give them }\end{array}$ \\
\hline 15 & 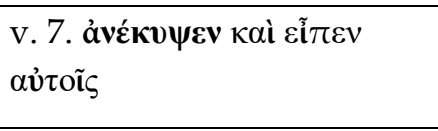 & $\begin{array}{l}\text { Jesus } \\
\text { straightened } \\
\text { up }\end{array}$ & $\begin{array}{l}\text { торєv́ov ảvá } \beta \eta \theta \imath \text { (Exod. } \\
33.1)\end{array}$ & Moses went up \\
\hline 16 & 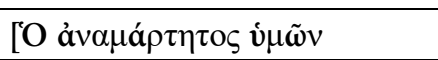 & throw a stone & $\varepsilon \varepsilon^{\prime} \rho \rho \psi \varepsilon v$ ả $\pi \grave{o} \tau \tilde{\omega} \nu \chi \varepsilon 1 \rho \tilde{\omega} V$ & he threw the tablets \\
\hline
\end{tabular}




\begin{tabular}{|c|c|c|c|c|}
\hline & \multicolumn{2}{|c|}{ Codex Bezae (Jn 7.53-8.11) } & \multicolumn{2}{|c|}{ Exod. 31-33LXX } \\
\hline & 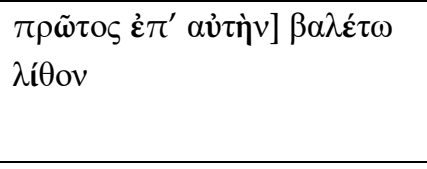 & at her & 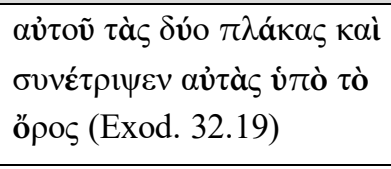 & $\begin{array}{l}\text { from his hands and } \\
\text { broke them at the } \\
\text { foot of the } \\
\text { mountain }\end{array}$ \\
\hline 17 & 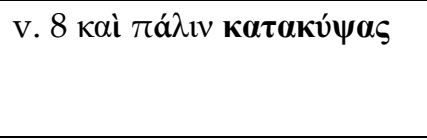 & $\begin{array}{l}\text { And once } \\
\text { again he bent } \\
\text { down }\end{array}$ & 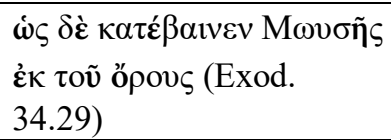 & $\begin{array}{l}\text { Moses came down } \\
\text { the mountain }\end{array}$ \\
\hline 18 & 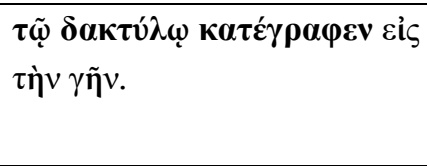 & $\begin{array}{l}\text { Jesus again } \\
\text { wrote on the } \\
\text { ground (Jn } \\
8.8 \text { ) }\end{array}$ & (see above) & $\begin{array}{l}\text { God wrote the } \\
\text { tablets again }\end{array}$ \\
\hline 19 & 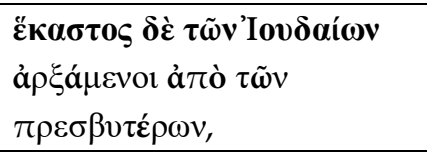 & $\begin{array}{l}\text { each of the } \\
\text { Jews left }\end{array}$ & 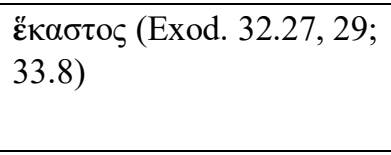 & $\begin{array}{l}\text { each of them [the } \\
\text { people of Israel] }\end{array}$ \\
\hline 20 & 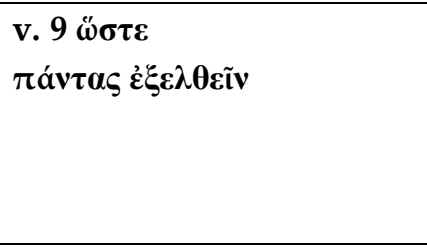 & $\begin{array}{l}\text { so that } \\
\text { everybody } \\
\text { left }\end{array}$ & 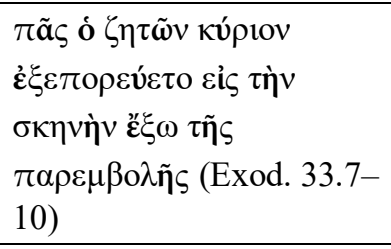 & $\begin{array}{l}\text { and everyone who } \\
\text { sought the Lord } \\
\text { would go out to the } \\
\text { tent of meeting, } \\
\text { which was outside } \\
\text { the camp. }\end{array}$ \\
\hline 21 & 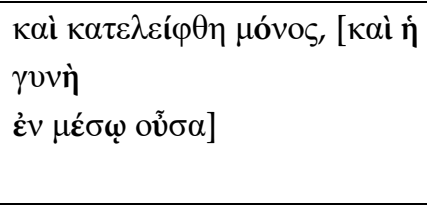 & $\begin{array}{l}\text { They left him } \\
\text { [Jesus] alone } \\
\text { [the woman } \\
\text { being in the } \\
\text { middle] }\end{array}$ & 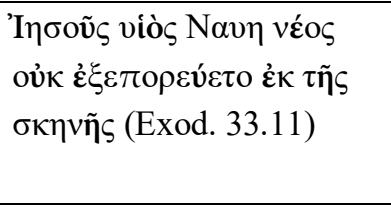 & $\begin{array}{l}\text { Joshua }[=\text { Jesus] is } \\
\text { alone in the tent }\end{array}$ \\
\hline 22 & 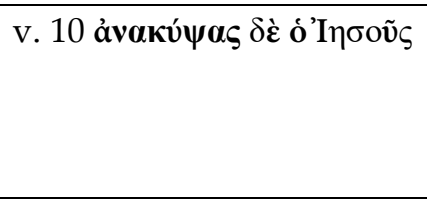 & $\begin{array}{l}\text { Jesus } \\
\text { straightened } \\
\text { up }\end{array}$ & 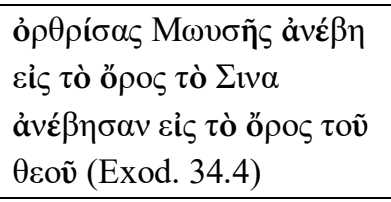 & $\begin{array}{l}\text { Moses went up the } \\
\text { mountain }\end{array}$ \\
\hline 23 & 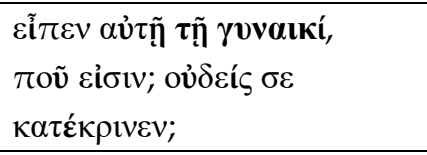 & $\begin{array}{l}\text { [dialogue } \\
\text { with the } \\
\text { woman] }\end{array}$ & [Exod. 33] & $\begin{array}{l}\text { [dialogue with } \\
\text { God] }\end{array}$ \\
\hline 24 & 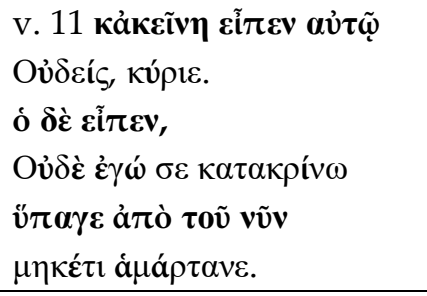 & $\begin{array}{l}\text { [Jesus let her } \\
\text { go] }\end{array}$ & [Exod. 34.1] & $\begin{array}{l}\text { [God reiterated his } \\
\text { Covenant and let } \\
\text { the people go] }\end{array}$ \\
\hline
\end{tabular}

As pointed out above, both Rius-Camps and Keith highlighted in their writing what appeared to them to be the significance of the parallels between the Gospel story and the incident recorded in Exodus.

Before commenting on that, something needs to be said about the use of the Torah in Jewish exegesis. In Jewish exegesis, catchwords ("hooks") are used in order to highlight the significance of a particular episode by referring it to an earlier one, a technique used in part for interpreting and explaining contemporary events. The reason for this is that any event happening in the course of the history of Israel can be typically regarded in Jewish understanding as an illustration of an earlier experience already described in the Torah. From the earliest times, Jewish scriptural writers and exegetes linked stories by using familiar 
catchwords signalling thereby to their audience that they were alluding to other references already contained in the Torah. ${ }^{32}$

Regarding the New Testament as Scriptures, it has been convincingly suggested that evidence of this technique can be identified in the text-critical study of variant readings which much of the time correspond to lectiones difficiliores. ${ }^{33}$ The correct deciphering of such allusions involves the understanding of the Scriptures from a Jewish perspective to be able to identify the events and thereby identify the "right" (i.e. intended) catchword or lemma, which may otherwise be treated at times as insignificant, in order to find the "right" link between different episodes. ${ }^{34}$ Traces of such overlaps between the Scriptures can be seen as cases of intertextuality.

As to the PA and its link with the Golden Calf, it needs to be remembered that Exod. 32 is traditionally seen in rabbinic tradition as the sin of the people of Israel par excellence (SUOMALA 2004, p. 91). Indeed, the last answer of the people to Moses before the episode of the Golden Calf appears to be a sincere commitment to obedience to God: "Moses came and told the people all the words of the LORD and all the ordinances; and all the people answered with one voice, and said, "All the words that the LORD has spoken we will do." (Exod. 24.3)

In the event, despite the solemnity of their statement, the first thing that the people do is go to other gods, that is, commit an adulterous act by worshipping other gods in the form of a golden calf. ${ }^{35}$ In view of the number of Torah references made in the PA, the latter can be seen to serve as a re-enactment of the incident of the Golden Calf, ${ }^{36}$ taking a prototypical story that was transmitted as part of the history of Israel. The purpose would have been to identify the woman as the people of Israel: though saved by God, she turned to other gods, but was nevertheless given a second chance, through a New Covenant.

\section{Reasons for the Location and Modification of the PA}

Once the reason for the existence of intertextuality between the Golden Calf episode and the PA as it stands in Codex Bezae has been confirmed, the question remains as to why this

\footnotetext{
${ }^{32}$ On Jewish exegetical techniques, see Rius-CAMPS, READ-HEIMERDINGER 2004, p. 24-25, and READHEIMERDINGER 2014, p. 71-92; 2012, p. 95-108, for bibliographical references.

${ }^{33}$ As an illustration, Read-Heimerdinger has identified the episode of the disciples of Emmaus (Lk. 24.1348 ) as a re-enactment of Jacob's dream at Bethel in Gen 28, the catchword being Ov $\alpha \mu \mu \alpha \alpha$ ov 5 (Oulammaus)

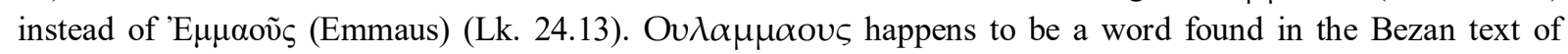

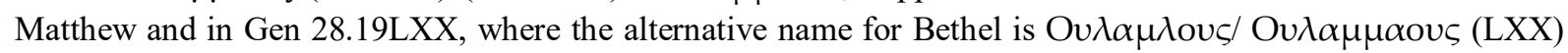
for Bethel ("He called that place Bethel; but Luz (לוּז אוּדם) was the name of the city at the first" (Gen 28.19). From this discovery, she goes on to show the parallels between Jacob's story and the account of the two disciples, explaining thereby all the other Bezan readings that give an entirely different flavour to Lk. 24 (READHEIMERDINGER 1999, p. 229-244). This is but one example of the application of exegetical techniques from the Jewish Scriptures in Luke's writings in Codex Bezae; for Acts see, e.g., READ-HEIMERDINGER 1994, p. 303-310.

${ }^{34}$ See PINCHARD 2015, p. 418-430 for examples of apparently harmonistic v.ll in Codex Bezae eventually revealing further striking features of intertextuality with the Jewish Scriptures.

${ }^{35}$ Exod. 32 is probably also a non-historical event consists in a paradigmatic imagery of the criticism made against the calves in Bethel and Dan erected by Jeroboam (1 Kings 12.26-30).

${ }^{36}$ On the concept of re-enactment of stories from the Jewish Scriptures, see READ-HEIMERDINGER 2003, p. $263-280$.
} 
piece of extraneous material was put in John; and why some manuscripts put it in Luke. Ideally, the answers will explain the reasons for all the various locations simultaneously.

The question is partially answered by Amphoux in his approach to the history of the canon of the New Testament. His suggestion is that while the PA should be viewed as material extraneous to any of the four Gospels as such, it was deliberately placed at the rhetorical centre $^{37}$ of the four Gospels in the arrangement in which they are found in some manuscripts including Codex Bezae ${ }^{38}$, namely Matthew-John-Luke-Mark. Amphoux argues that the Matthew-John-Luke-Mark order was that of the final redaction of the first edition of the four Gospels created in Smyrna by Polycarp in the first decades of the $2^{\text {nd }} \mathrm{c}^{39}$ The effect of placing the PA at Jn 7.53 is to make it the point saillant of the overall Gospel collection. ${ }^{40}$ This hypothesis is a strong one. It confers on the PA a deliberately unique status in the final redaction of the Gospels (AMPHOUX 2013a, p. 161). Furthermore, Amphoux explains the nonJohannine character of the passage by claiming that it was derived from the Gospel to the Hebrews and inserted by Luke in his Gospel, as attested in $f^{13}$ (AMPHOUX 2013a, p. 162-164). Rius-Camps refines this analysis by further suggesting that the reason for variant readings between $f^{13}$ and Codex Bezae is the existence of two distinct traditions of the PA. ${ }^{41}$ This is to say that $f^{13}$, a family of manuscripts dated to the $11^{\text {th }} \mathrm{c}$., reflects a much earlier state of text than that found in other manuscripts. ${ }^{42}$

\footnotetext{
${ }^{37}$ On the definition of a "centre" or "middle [point]" as a philosophical conception used to attest divine inspiration of the Scriptures, see AMPHOUX 2008, p. 9-26, and for its illustration to the PA, see AMPHOUX 2013a, p. 157-159. The centre is here defined by Amphoux as the point in the redaction of the Four Gospels where the PA divides the fourfold corpus into equal parts of Jesus' discourses and twice the amount of narratives after the PA (the latter ratio being referred to as a proportion du simple au double) (see Amphoux 2014, p. 368). Gothic.

${ }^{38}$ Other manuscripts with the "Western" order of Gospels are $\mathfrak{P}^{45}, \mathrm{~W}, \mathrm{X}$, the Old Latin $(a$ b e f ff $q$ ) and

39 “Le corpus de Marcion serait, en somme, d'abord constitué par Polycarpe, l'éditeur probable d'un double corpus, à Smyrne, vers 120-130 : celui des quatre évangiles dans l'ordre Matthieu - Jean - Luc - Marc, formant autour de la Femme adultère (introduite dans Jean en 7,53-8,11) une double proportion : d'égalité, pour les paroles de Jésus, et du simple au double, pour les parties narratives ; et celui des lettres pauliniennes, disposées dans la proportion du simple au double inversée, pour compléter la double proportion précédente" (AMPHOUX 2013b, p. 87-104).

${ }^{40}$ AMPHOUX 1995, p. 72-73, uses a similar reasoning to suggest that the disputed longer reading at the end of Mk. 16 is an epilogue to the collection of the four Gospels where Mark's concludes the series, an epilogue that was omitted after the later rearrangement of the Gospels in the familiar order (Matthew-Mark-Luke-John).

${ }^{41}$ By a detailed study of the language, RIUS-CAMPS 2007, p. 403-405, identifies one tradition initially composed by Mark, which is the form of the PA found in Codex Bezae (pace its placing there in the Gospel of John), and another composed by Luke, as attested by $f^{3}$. His innovative proposal offers a convincing solution to the existence of the two forms and locations of the passage (RIUS-CAMPS 2007, p. 395-396). His conclusions were challenged by KEITH 2009b, p. 209-231), but it should be noted that despite a thorough and extensive examination of the documentary evidence, Keith's refutation ultimately rests on the fact that all early manuscripts have the PA in John, the earliest being Codex Bezae. However, this argumentation depends on the misconception that late copies reflect late texts, whereas they can just as well reflect an earlier text. On this topic see EHRMAN 2006: "This criterion [the age of supporting witnesses] is not foolproof either, however, since a $7^{\text {th }}$ c. manuscript could, conceivably, have been copied from an exemplar of the $2^{\text {nd }}$ century, whereas a $6^{\text {th }} \mathrm{c}$. manuscript (which is therefore older) could have been copied from one of the $5^{\text {th }}$ century."

${ }^{42}$ A similar example on the antiquity of a text can be illustrated by the text of the Lord's Prayer in Luke transmitted in minuscule $700\left(11^{\text {th }} \mathrm{c}\right.$ !), which is the form referred to as original by Gregory of Nyssa $\left(4^{\text {th }} \mathrm{c}\right.$. $)$. See AMPHOUX 1999, p. 10.
} 
Given the meaning expressed by a deliberate building of the PA on the Golden Calf incident, the PA would have served as a theological comment to present Jesus in the position of God writing the Tablets "with his finger" and as a (new) Law-giver - and the woman caught in adultery as a figure of Israel's sin. Because the parallel between Jesus and God would have been understood as too forceful an assessment against transcendence, later scribes may have been inclined to "correct" readings into a simpler text, leading to a more straightforward narrative. The strong parallels between Jesus and Moses or even God and the episode of the woman and that of the Golden Calf are only retained in isolated traditions, such as that transmitted by Codex Bezae, reflecting thereby an early text. However, it seems from the various alternative readings and subsequent emendation of the text of the PA, that the pericope was gradually understood as a simple rhetorical question regarding a woman caught in adultery and the passage was either eventually withdrawn, or moved: either the passage was considered as inappropriate in the Gospels because of its motive, or it is the fact that Jesus was forgiving one of the sins explicitly mentioned in the Ten Commandments that was considered as far too provocative by the standards of the newly established Church. ${ }^{43}$ Any of these reasons would have given grounds for its withdrawal from the Gospels, as it is the case in Codex Vaticanus.

Yet, the fact that the position of the PA has moved so drastically, a unique feature in the Gospels, is certainly an illustration of an underlying nature of this episode as understood in the first centuries. In the precise context of the PA, the inappropriateness of the theme may have led to the smoothing out of the parallels with Exodus and turned it into a local and somewhat commonplace story on Jesus' kindness towards a woman caught in adultery. The position of a non-Johannine passage, not only in John but at the very centre of the four Gospels, is most probably a deliberate indication aimed at alerting the audience to the specific character of this episode to stand out as a re-enactment of the sin of the people in the Golden Calf.

\section{Conclusions}

Intertextuality, specifically in Codex Bezae, is no new area of research in textual criticism, but it has rarely been undertaken systematically because of the general tendency to study variant readings in isolation, that is, as omissions or additions or substitutions with regard to the generally accepted text of the Greek edition of the New Testament. Specifically, singular readings are rarely regarded as original; on the contrary, they are viewed as scribal accidents that were simply ignored for being "wrong" or nonsensical. There is, however, an alternative explanation, namely that some singular readings could actually transmit a very early text that was altered at a date before the authoritative text was fixed. It is my contention that this is the case here in the text of Codex Bezae or rather, its faithfully copied exemplar. ${ }^{44}$

This article has sought to show that there are striking points of contact between Exod. 32 and $\mathrm{Jn} 7.52-8.11 \mathrm{D}$, in terms of both lexical and thematic proximity, in contrast to the PA in other manuscripts; and, building on that proximity, that the Gospel story of the woman caught

\footnotetext{
${ }^{43}$ Amphoux explains the intertextuality differently and refers to the PA as an allegory for the Christian predication of hope (AMPHOUX 2013a, p. 161-62).

${ }^{44}$ On the other hand, scholarship on Codex Bezae over the last 30 years has put forward considerable evidence to suggest that this manuscript has preserved a text that is much earlier than the date of its copying and also earlier than the date of the standardisation of the text transmitted in the manuscripts of the Alexandrian tradition. For Acts, for example, see READ-HEIMERDINGER 2012, p. 95-108; 2014, p. 71-92.
} 
in adultery can be viewed as a re-enactment of the people caught in adultery at Mont Sinai in Exod. 32. Subsequently, the original story would have been transmitted as a simple narrative about an adulterous woman, omitting the Jewish exegetical clues that initially made the connection with the Exodus event.

Had the PA not been related to Exod. 32 in its first form, it pushes the boundaries of probability to think that a scribe, in this case the copyist of what will become Codex Bezae, would have taken a story involving Jesus and a woman and incorporated enough hints into it by adding, omitting and substituting words to make a text that was originally unrelated match the Exodus episode perfectly. In other words, the explanation that the readings in Codex Bezae reflect a scribe who would have lexically "bent" the story of Jesus encountering a woman accused of adultery to the extent that it would look like a replica of the Golden Calf story is quite implausible.

Rather than posit that it was a later scribe or an interpolator of the $5^{\text {th }} \mathrm{c}$. who would have been aware of Jewish exegesis - a quite unlikely hypothesis! -deliberately linked both stories intertextually by use of various stylistic or lexical emendations, it is a more reasonable to deduce that the PA is a deliberate and original composition. A composition built on the model of the Jewish story of the Golden Calf as a paradigmatic illustration of the adulterous sin of people against God.

On this understanding, the "Bezan scribe" would in fact have carefully reproduced an exemplar that was well established at the time of Papias, dating therefore to the years of Polycarp of Smyrna. ${ }^{45}$ The text would have probably been composed in the first instance as an addendum or a separate story, as the placing of the pericope in such a high number of textual locations - a unique case of volatility! - testifies.

I contend that the consequences of such findings are significant for a text-critical approach to this passage in particular, and the early character of the textual form of the "Western" text of this passage in general. While the "Western" text is usually said to represent a form of text that systematically departs from the Ausgangstext as a result of an enthusiastic scribe freely re-writing the text, the aforementioned examples show a consistent use of Jewish references to Exodus $-\mathrm{a} 1^{\text {st }} \mathrm{c}$. feature distinctively found in Bezae ${ }^{46}$-suggest that the readings of Codex Bezae reflect the original version of the episode, thereby representing the intention to activate a link with the story of the Golden Calf, once the incident came to be a simple encounter between Jesus and the woman. It would be natural, therefore, that later manuscripts show signs of scribal emendation, including lexical simplification, simply referring to an adulterous woman. The implicit link to Exod. 32 would be put aside as this paradigm rapidly ceased to be understood or recognised, and was taken instead at face value as a simple encounter between Jesus and an adulterous woman, a story highlighting Jesus's mercy towards an apparently unforgiveable sin with regard to the Law.

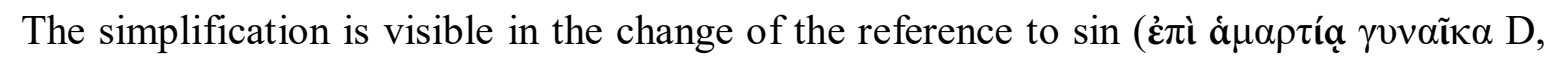

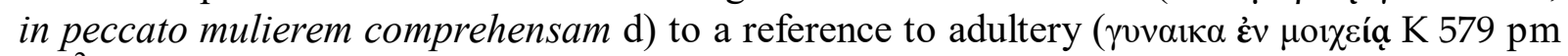
$\mathrm{c} \mathrm{ff}^{2}\left[\mathrm{vg}^{\mathrm{mss}}\right]$, mulierem in adulterio deprehensam $\left.\mathrm{vg}\right)$. The verb indicating the tablets of stones ( $\left.\lambda_{1} \theta \dot{\alpha} \zeta \varepsilon v v\right)$ shifted to indicate the act of stoning ( $\lambda_{1} \theta$ o $\left.\beta o \lambda \varepsilon \varepsilon^{\prime} \sigma \theta \alpha_{1} \mathrm{~K} 579 \mathrm{pm}\right)$ and the reference to

\footnotetext{
${ }^{45}$ According to EuseBIUs, Adv. Haer. 5, 33, 4.

${ }^{46}$ The example presented in this article adds to the numerous instances of intertextuality between Codex Bezae and the Jewish Scriptures that have already been, to my mind convincingly, adduced in other passages of the manuscript (see Read-Heimerdinger 1994a, 1994b, 1999 and Pinchard 2015).
} 
Jesus's saying was qualified by the addition of "about her" ( $\pi \varepsilon \rho \grave{i} \alpha \mathbf{v} \tau \tilde{\eta} \varsigma f^{13} 700.1424^{\mathrm{mg}} \mathrm{pm} \mathrm{c}$ $\mathrm{ff}^{2}$ ), here again, losing the paradigmatic allusion. The reference to the inscription on the

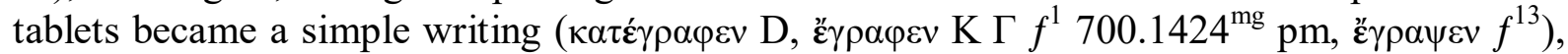
the second reference to "the finger" in connection with the writing was omitted as being superfluous (v.6b, v. 8: om. $\tau \tilde{\omega} \delta \alpha \kappa \tau \nu \lambda \omega$ all but $\mathrm{D} \mathrm{ff}^{2}$ ), so removing the original deliberate signalling of the Exodus reference, which had the effect of underlining and reinforcing the link for the benefit of the audience (he wrote, with his finger, twice [i.e. "do you, audience, understand the allusion with the Exodus passage?"]). My contention here is to note that the 24 points of exact lexical overlap between the PA and the Golden Calf is substantial enough to conclude that there is a link more likely to be deliberate, and that therefore the PA looks as if it was intentionally designed on the basis of the Golden Calf.

Given the complexity of the connection between the Gospel text and the Exodus incident, it follows that it is quite unlikely that a single scribe or a school of scribes could have taken an original text referring to an adulterous woman and twisted it to the extent that it was turned into a re-enactment of the Golden Calf episode. In consequence, it is reasonable to contend that the text corresponds to the original intention of the one(s) composing the account.

A study of the choice of specific words by Codex Bezae allows a probable reference to the Golden Calf story to be posited, based on a close lexical analysis of the manuscript's readings. The cumulative evidence of previous scholarship concurs with the findings of the present article, including the work of Amphoux (identifying the unexpected position of the PA, deliberately placed at the rhetorical centre of the Four Gospels in the "Western order"); of Rius-Camps (suggesting an original placing of the PA in Mark before it was placed in John); and of Keith (identifying the Exodus reference of the variant reading $\gamma \rho \alpha ́ \varphi \omega / \kappa \alpha \tau \alpha \gamma \rho \alpha ́(\varphi \omega)$. All this evidence tends to confirm that we have in Codex Bezae a very early and carefully transmitted reading.

Beyond the lexical analysis of the PA as transmitted by Codex Bezae, previous studies have also proposed reasons for the various displacements of the PA in early to late manuscripts. While no consensus has been reached, scholars have put forward cogent theses, among which mention may be made of Robinson's theory about the PA fitting the Byzantine liturgy and therefore nicely placed in John with a lexical arrangement not untypical in John's writing, or Keith's extensive analysis of the Johannine setting of the passage's first interpolation.

In this article, I suggest that the history of the displacement of the PA among the Gospels is also closely linked to the notion of the woman caught in adultery as a paradigm. Had this been a mere fait divers about an adulterous woman, one would hardly see what possible discomfort should cause it to be removed from its original place. The history of the various locations attested shows that the PA is anything but a fait divers.

The aim of this article has not been to solve a historical, literary problem by means of textual criticism and without regard for the question of the diverse locations the PA has occupied in the transmission of the New Testament. Rather, the goal has been more modest, to set out reasons for believing that the Bezan text transmits the original composition which presents in the PA the re-enactment of an ancient story, one that serves as a paradigm within Jewish history. Contrary to the usual view of Codex Bezae as the best, free-floating representative of the "Western" text (D-text), the PA constitutes another example to add to those already adduced by other scholars which indicates that it is closer to the Ausgangstext than other MSS, notably by virtue of its coherence with the use made of scriptural paradigms in Jewish exegesis. 
Codex Bezae is so often seen as a textual curiosity with all the mystery around its unknown origin, the uncertain identity of the scribe, its presence in text of both the West and the East, as well as its striking differences compared with the rest of the manuscript tradition. With this analysis of the PA however, the tables are turned: by its use of a typical Jewish exegesis to interpret a contemporary event on the basis of an ancient Torah model, the text transmitted by Codex Bezae stands right at the beginning of the composition of the pericope; it is only at a second stage that its re-enactment narrative evolves into a simple description of an encounter between a woman and Jesus. ${ }^{47}$

${ }^{47}$ I would like to acknowledge the assistance provided by Dr. Jenny Read-Heimerdinger in correcting the English of this article. I take the responsibility for any mistakes remaining in the final draft. 


\section{BIBLIOGRAPHY}

Aland, Aland 2012: B. Aland, K. Aland, J. Karavidopoulos, C.M. Martini, and B.M. MetzGER, Novum Testamentum Graece, Stuttgart, Deutsche Bibelgesellschaft. [NA ${ }^{28}$ or Nestle-Aland $\left.{ }^{28}\right]$.

Aland, Aland 1995: K. Aland, B. Aland, The Text of the New Testament: An Introduction to the Critical Editions and to the Theory and Practice of Modern Textual Criticism (trans. E.F. Rhodes), Grand Rapids, Eerdmans.

AlLison 2000: D.C. Allison, The Intertextual Jesus: Scripture in Q, Harrisburg, PA, Trinity International Press.

Amphoux 1995: C.-B. Amphoux, “L'Évangile selon les Hébreux, source de l'Évangile de Luc", Apocrypha, 6, p. 67-77.

Amphoux 1996: C.-B. Amphoux, "Le texte", in D.C. PARKer and C.-B. Amphoux (ed.), Codex Bezae: Studies from the Lunel Colloquium, June 1994, Leiden, Brill, p. 337-354.

Amphoux 1999: C.-B. Amphoux, "Le texte évangélique de Césarée et le type de texte 'césaréen' des Évangiles”, FilNeo, 12, p. 3-16.

Amphoux 2008: C.-B. Amphoux, "Le Canon du Nouveau Testament avant le IV siècle", FilNeo, 21, p. 9-26.

Amphoux 2013a: C.-B. Amphoux, "La place de l'épisode de la Femme adultère (Jn 7,538,11)", in F.L. Roig LANZillotta and I. MunOz-GAllarte (ed.), Greeks, Jews and Christians, Historical, Religious and Philological Studies in Honor of Jesús Peláez del Rosal (Estudios de Filología Neotestamentaria, 10), Córdoba, El Almendro, p. 149-165.

Amphoux 2013b: C.-B. Amphoux, "Les lieux de rédaction des lettres de Paul d'après la tradition manuscrite", BABELAO, 2, p. 87-104.

AMPHOUX 2014: C.-B. AMPHOuX, "Le projet littéraire d'Ignace d'Antioche", in P. DoBle and J. KlOHA (ed.), Texts and Traditions. Essays in Honour of J. Keith Elliott (NTTSD, 47), Leiden/Boston, Brill, p. 348-369.

Black, Cerone 2016: D.A. Black, J.N. Cerone, The Pericope of the Adulteress in Contemporary Research (LNTS, 551), London/New York, Bloomsbury/T\&T Clark.

EHRMAN 2006: B.D. EHRMAN, Studies in the Textual Criticism of the New Testament (NTTS, 33), Leiden/Boston, Brill,.

EpP 2005: E.J. EpP, Perspectives on New Testament Textual Criticism. Collected Essays, 1962-2004 (NovTSup, 116), Leiden/Boston, Brill,.

EpP 2007: E.J. EPP, “It's All about Variants: A Variant-Conscious Approach to New Testament Textual Criticism", HTR, 100, p. 275-308.

FEE 2012: G.D. FEE, "The Use of the Greek Fathers for New Testament Textual Criticism", in B.D. Ehrman and M.W. Holmes (ed.), The Text of the New Testament in Contemporary Research: Essays on the Status Quaestionis, A Volume in Honor of Bruce M. Metzger $\left(2^{\text {nd }}\right.$ ed.; NTTSD, 42), Leiden/Boston, Brill, p. 351-373.

Hughes 2013: K.R. Hughes, "The Lukan Special Material and the Tradition History of the Pericope Adulterae", NovT, 55, p. 232-251.

KeITH 2008: C. KeITH, "Recent and Previous Research on the Pericope Adulterae (John 7.538.11)", CBR, 6, p. 377-404. 
KeITH 2009a: C. KeITH, The Pericope Adulterae, the Gospel of John, and the Literacy of Jesus (NTTSD 38), Leiden, Brill.

KeIth 2009b: C. KeITH, "The Initial Location of the Pericope Adulterae in Fourfold Tradition", NovT, 51, p. 209-231.

KNUST 2006: J.W. KNUST, "Early Christian Re-Writing and the History of the Pericope Adulterae", JECS, 14, p. 485-536.

LEVINSOHN 2000: S.H. LEVINSOHN, Discourse Features of New Testament Greek: A Coursebook on the Information Structure of New Testament Greek ( $2^{\text {nd }}$ ed.), Dallas, SIL International.

PAyne, CANART 2000: P.B. PAyne, P. CANART, "The Originality of Text-Critical Symbols in Codex Vaticanus", NovT, 42, p. 105-113.

PARKer 1992: D.C. PARKer, Codex Bezae. An Early Christian Manuscript and Its Text, Cambridge, Cambridge University Press.

PINCHARD 2015: L. PINCHARD, "Des traces vétérotestamentaires dans quelques variantes du Codex de Bèze traditionnellement jugées harmonisantes", NovT, 57, p. 418-430.

Punch 2016: J.D. PunCH, "The Piously Offensive Pericope Adulterae", in D.A. BLACK and J.N. CERONE (ed.), The Pericope of the Adulteress in Contemporary Research (LNTS, 551), London/New York, Bloomsbury/T\&T Clark, p. 7-32.

READ-Heimerdinger 1994a: J. READ-Heimerdinger, “The Seven Steps of Codex Bezae: A Prophetic Interpretation of Acts 12", in D.C. PARKER and C.-B. AMPHOUX (ed.), Codex Bezae: Studies from the Lunel Colloquium, June 1994, Leiden, Brill, p. 303-310.

READ-Heimerdinger 1994b: J. READ-Heimerdinger, "The Apostles in the Bezan Text of Acts", in T. NicKlas and M. Tilly (ed.), The Book of Acts as Church History: Text, Textual Traditions and Ancient Interpretations/Apostelgeschichte als Kirchengeschichte: Text, Texttraditionen und antike Auslegungen (BZNW, 120), Berlin/New York, Walter de Gruyter, p. 263-280.

READ-HEIMERDinger 1999: J. READ-HeIMERDinger, "Where is Emmaus? Clues in the Text of Luke 24 in Codex Bezae", in D. TAYLOR (ed.), Studies in the Early Text of the Gospels and Acts. The Papers of the First Birmingham Colloquium on the Textual Criticism of the New Testament (SBLTCS, 1), Atlanta, Society of Biblical Literature, p. 229-244.

ReAD-Heimerdinger 2002: J. READ-HeIMERdinger, The Bezan Text of Acts: A Contribution of Discourse Analysis to Textual Criticism (JSNTSup, 236), Sheffield, Sheffield Academic Press.

READ-HEIMERDINGER 2012: J. READ-HeIMERDingeR, "Le Codex de Bèze : un texte précanonique du Nouveau Testament", in A.-L. ZwILling (ed.), Lire et Interpréter, Geneva, Labor et Fides, p. 95-108.

READ-HEIMERDINGER 2014: J. READ-HEIMERDINGER, "Eclecticism and the Book of Acts", in P. Doble and J. Kloha (ed.), Texts and Traditions. Essays in Honour of J. Keith Elliott (NTTSD, 47), Leiden/Boston, Brill, p. 71-92.

RIUS-CAMPS 1993: J. RIUS-CAMPS, “Origen lucano de la perícopa de la mujer adúltera", FilNeo, 12, p. 171-73.

RIUS-CAMPS 2007: J. RIUS-CAMPS, "The Pericope of the Adulteress Reconsidered: The Nomadic Misfortunes of a Bold Pericope", NTS, 53, p. 379-405. 
RIUS-CAMPS, READ-HEIMERDINGER 2004: J. RIUS-CAMPS, J. READ-HEIMERDINGER, The Message of Acts in Codex Bezae: A Comparison with the Alexandrian Tradition. Vol.1 Acts 1.1-5-42: Jerusalem, London/New York, T. \& T. Clark.

Rius-CAMPS, READ-HEIMERDINGER 2014: J. Rius-CAMPS, J. READ-HEIMERDINGER, A Gospel Synopsis of the Greek Text of Matthew, Mark and Luke. A Comparison of Codex Bezae and Codex Vaticanus (NTTSD, 45), Leiden, Brill.

RoBINSON 2000: M.A. RoBINSON, "Preliminary Observations Regarding the Pericope Adulterae Based upon Fresh Collations of Nearly All Continuous-Text Manuscript and All Lectionary Manuscripts Containing the Passage", FilNeo, 13, p. 35-59.

SCRIVEner 1864: F.H. SCRIVEnER, Bezae Codex Cantabrigiensis, Deighton, Bell \& Co, Cambridge (repr. 1978), Pittsburgh, Pickwick Press.

Suomala 2004: K.R. Suomala, Moses and God in Dialogue: Exodus 32-34 in Postbiblical Literature (StBL, 61), New York, Peter Lang. 